\title{
Screening of Fungi from Disposed Maize Cobs for Amylase Production
}

\author{
Oguche $\mathrm{SO}^{1 *}$, Iliyasu $\mathrm{MY}^{1}$, Ahmad $\mathrm{A}^{2}$, Abba $\mathrm{M}^{2}$, Karamba $\mathrm{KI}^{2}$, Haruna US ${ }^{3}$, \\ Na'Allah $\mathrm{AJ}^{3}$ and Agbo E $\mathrm{B}^{1}$ \\ ${ }^{1}$ Department of Microbiology, Abubakar Tafawa Balewa University, ATBU, Nigeria \\ ${ }^{2}$ Department of Microbiology, Bauchi State University Gadau (BASUG), Nigeria \\ ${ }^{3}$ Department of Food Science and Technology, Federal Polytechnic, Nigeria
}

\section{Research Article}

Volume 6 Issue 4

Received Date: November 29, 2021

Published Date: December 15, 2021

DOI: $10.23880 /$ oajmb-16000207

*Corresponding author: Oguche SO, Department of Microbiology, Abubakar Tafawa Balewa

University, ATBU, Nigeria, Email: myiliyasu@atbu.edu.ng

\section{Abstract}

Background of Study: Microorganisms in particular have been regarded as treasure of useful enzymes. There is a great variation between various genera as to their ability to produce a specific enzyme for the production of particular enzymes varies with the particular medium and $\mathrm{pH}$.

Place and Duration of Study: The study was conducted at the Department of Microbiology Laboratory, Abubakar Tafawa Balewa University, ATBU, Bauchi Nigeria, from November, 2020 to October, 2021.

Aim: This study was aimed to isolates fungi from disposed maize cobs and evaluates its potentials to produce amylase.

Methods: Twelve samples each was collected from three different areas; market place, farmland and residential areas in Bauchi metropolis, (a total of 36 samples in all) using precise aseptic techniques. Each sample was collected using clean polythene bag, transported to the lab and aseptically blended. One gram of each sample was aseptically weighed and placed in a test tube containing sterile water; it was then allowed to stand for 30 minutes. One $\mathrm{ml}$ of the stock solution was serially diluted and $10 \mathrm{ml}$ dilution of each sample was plated on Potato Dextrose Agar (PDA) media. The plate was incubated at $25^{\circ} \mathrm{C}$ within a period of three, five and seven days during which they were monitored and examined, to isolate the required fungi species. The isolates were tested for amylolytic activity using $1 \%$ iodine and screen for amylase production by pre-treatment and solid state fermentation, then $\alpha$-amylase activity finally determined.

Results: Amylase-producing fungi were isolated from maize cobs collected from residence, market and farm areas in Bauchi metropolis. The ability of ten (10) fungal isolates recovered, (Mucor racemosus, Aspergillus niger Penicillium chrysogenum, Rhizopus oryzae, Microsporum sp, Trichoderma sp, Nocardia sp, Monilla sp, Fusarium sp and Chaetomum sp) to degrade starch was determined. Three (3) of the fungal isolates Aspergillus niger Penicillium chrysogenum, Rhizopus oryzae, had the highest frequency of (20\%) each. Four (4) of the fungal isolates (Mucor racemosus, Aspergillus niger, Penicillium chrysogenum and Rhizopus oryzae) showed zone of clearance on starch agar medium, the fungi isolates were selected and subjected to various temperatures, incubation time and $\mathrm{pH}$ ranges for amylase production. The results showed that Penicillium chrysogenum and Rhizopus oryzae have maximum amylase activity at temperature $35^{\circ} \mathrm{C}$, incubation time $96 \mathrm{hrs}$ ( 4 days), $\mathrm{pH} 5.5$ and temperature $30^{\circ}$, incubation time $96 \mathrm{hrs}$ (4days) and $\mathrm{pH} 5.0$ respectively. Penicillium chrysogenum produced $46.3 \mu / \mathrm{ml}$, and Rhizopus oryzae, produced $30.8 \mu / \mathrm{ml}$ of amylase.

Conclusion: The results of this work proved Penicillium chrysogenum to be the best producer of amylase compared to Rhizopus oryzae. Isolation of amylase producing fungi from maize cobs from residence, market and farm areas will help in the bioremediation of environment, which could have caused environmental pollution. It is recommended that Penicillium chrysogenum and Rhizopus oryzae, are suitable fungi for amylase production. While Maize cobs can be used as substrate for commercial enzymes production. 


\section{Open Access Journal of Microbiology \& Biotechnology}

Keywords: Amylase; Fungi; Maize Cobs; Penicillium Chrysogenum; Rhizopus Oryzae

Abbreviations: PDA: Potato Dextrose Agar; OFAT: One Factor At a Time; DNS: Dinitrosalicylic Acid Method

\section{Introduction}

The main cereal crop grown in many parts of Nigeria is Maize (Zea mays). It is used primarily as staple food for human consumption, animal feeds and a raw material for industrial purposes [1]. Maize cob is an agricultural waste which is currently used as substrate for combustion. Due to its high contents of chlorine, the combustion has to take place in continuously monitored industrial power plants [2]. In recent years cellulolytic and amylolytic enzymes are used in Nigeria industries for the production and processing of chemicals, foods, and manufactured goods such as papers, rayon and cellophane among others [3]. Amylase is among the most important enzymes that hydrolyze starch releasing several products including dextrin, and progressively smaller polymers of glucose units [4]. Alpha-amylase (EC3.2.1.1, $\alpha$-1, 4-glucan-4-glucanohydrolysis), catalyzes the endo-cleavage of the $\alpha-1,4$-glucoside linkages and the release of short oligosaccharides and a- limit dextrin, this enzyme is used commercially for the production of sugar syrups from starch which consist of glucose, maltose and higher oligosaccharides [5-7]. Amylase can be derived from several source such as plants, animals, fungi and bacteria , fungal sources have gained much attention in industrial sector and large number of them are available commercially [8].

Agricultural and industrial waste such as cereals, straw, leaves, and maize cobs contribute to environmental pollution, the local production of enzymes using these locally available agricultural wastes as substrates reduce the cost of importation and encourage self-reliance [9]. These waste are highly underutilized in Africa including Nigeria and most part of the country, they are mostly used for animal feeds. Proper biotechnology utilization of these agricultural wastes in the environment will help to eliminates pollution and transforming them into useful byproduct and ameliorate the problem they cause [9]. Fungal sources have gained much attention in industrial sector and a large number of them are available commercially [10]. Filamentous fungi, such as Aspergillus oryzae and Aspergillus Niger, produce considerable quantities of enzymes that are used extensively in the industry. An oryzae has received increased attention as a favourable host for the production of heterologous proteins because of its ability to secrete a vast amount of high value proteins and industrial enzymes, e.g.-amylase [11].

\section{Materials and Methods}

\section{Isolation of Amylase-Producing Fungi}

Maize cobs were collected from different areas in Bauchi LGA of Bauchi state using precise aseptic techniques. The pour plate method as described by Cheesbrough M [12] was adopted. One (1) gram of each sample was aseptically weighed and placed in a test tube containing sterile water, it was allowed to stand for 30 minutes. One (1) $\mathrm{ml}$ of the stock solution was serially diluted and $10 \mathrm{ml}$ dilution of each sample was plated on Potato Dextrose Agar (PDA) media. The plate was incubated at $25^{\circ} \mathrm{C}$ for a period of 3-7 days during which they will be actually monitored and examined.

\section{Screening for Amylase Producing Fungi by Starch-reaction test}

The fungi isolates were inoculated into a starch agar plate using the streaking plate method, and incubated at room temperature for $72 \mathrm{hrs}$ and further tested for amylolytic activity, after which the plates were completely flooded with approximately $5 \mathrm{ml}$ of $1 \%$ 1grams iodine $2 \mathrm{~g}$ Potassium iodide,1g Iodine dissolved in $300 \mathrm{ml}$ distilled water) using Pasteur pipette to screen for amylase production, zone of clearance around the growth was observed and measured as coefficient of the diameter of the fungal colony formed and that of the hydrolysis zone around the colony as reported by Maki M and Soares, et al. [13,14].

The hydrolytic coefficient $(\mathrm{Hc})=\frac{\text { diameter of the colony }}{\text { diameter of the entire zoneof hydrolysis includin }}$ diameter of the entire zone of hydrolysis including the fungal colony

The maximum value of Hc is 1 , when there is no activity. The lower the value, the higher the activity. And the range

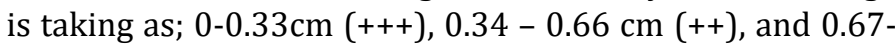
$0.99 \mathrm{~cm} \mathrm{(+).} \mathrm{When} \mathrm{there} \mathrm{is} \mathrm{no} \mathrm{activity} \mathrm{the} \mathrm{ratio} \mathrm{between} \mathrm{the}$ colonies to the hydrolysis zone diameter is 1 . Therefore it is assigned negative (-) Positive results of fungi isolates indicates yellow colour or clearing, while blue-black indicates negative, where starch has not been degraded [15].

\section{Production of Amylase Using the Positive Isolates}

The production medium used for the positive isolates were soluble starch (50)g, yeast extract $(0.5) \mathrm{g}, \mathrm{KH}_{2} \mathrm{PO}_{4}(10)$ $\mathrm{g},\left(\mathrm{NH}_{4}\right)_{2} \mathrm{SO}_{4}(10.5) \mathrm{g}, \mathrm{MgSO}_{4}(0.3) \mathrm{g}, \mathrm{CaCl}_{2}(0.5) \mathrm{g}, \mathrm{FeSO}_{4}(0.013) \mathrm{g}$, $\mathrm{MnSO}_{4}(0.004) \mathrm{g}, \mathrm{ZnSO}_{4}(0.004) \mathrm{g}, \mathrm{CuCl}_{2}(0.0067) \mathrm{g}$. In addition to this, agricultural waste product, maize cobs was used as solid state medium. The pH was adjusted to 6.5 , and the media was sterilized in an autoclave for $15 \mathrm{~min}$ at $121^{\circ} \mathrm{C}$. The media was inoculated with a loop-full of fungal spore suspension $(0.5 \mathrm{ml})$ and incubated at $30^{\circ} \mathrm{C}$ in an orbital shaker set at $100 \mathrm{rpm}$ for $72 \mathrm{hrs}$. The media was centrifuged at $5,000 \mathrm{~g}$ for 


\section{Open Access Journal of Microbiology \& Biotechnology}

15 min. Crude enzyme served as the enzyme source and the enzyme activity was assayed using the Dinitrosalicylic acid method (DNS) as described by Kwatia S, et al. [16].

\section{Optimization of the Cultural Conditions}

The factors such as $\mathrm{pH}$, temperature, under different incubation time, affecting production of enzymes were optimized by varying the parameters using one factor at a time (OFAT). The experiment was conducted in $250 \mathrm{ml}$ Erlenmeyer flask, containing $150 \mathrm{ml}$ of production medium for each parameter. After sterilization by autoclaving, the flask was cooled to a temperature below $40^{\circ} \mathrm{C}$ and inoculated with culture and maintained under various culture conditions as described by Bedan D, et al. [17].

Effect of Temperature on Enzyme Produced: Effect of temperature on enzyme production was investigated by inoculating fermentation medium which was later incubated at $25^{\circ} \mathrm{C}, 30^{\circ} \mathrm{C}, 35^{\circ} \mathrm{C}, 40^{\circ} \mathrm{C}$ and $50^{\circ} \mathrm{C}$

Effect of pH on Enzyme Produced: The effect of $\mathrm{pH}$ was studied by maintaining other culture conditions and the medium at constant while varying the $\mathrm{pH}$ of the medium at $4.0,4.5,5.0,5.5$ and 6.0

Effect of Incubation Time: The effect of incubation time was studied by varying the medium for $24,48,76,96$ and 120 hours.

\section{Results and Discussion}

\section{Fungal Isolates Obtained}

Micro-organisms in particular have been regarded as treasure of useful enzymes. There is a great variation between various genera as to their ability to produce a specific enzyme, the production of particular enzymes varies with the particular medium, temperature, $\mathrm{pH}$ and incubation time. In recentyears, the uses of microorganisms have become a huge importance to food, textile, baking and detergent industries and sparked a large interest into the exploration of enzyme activity in microorganisms [18]. This study was focused on assessing the ability of several fungi in producing amylase, at different temperature, time and $\mathrm{pH}$. The finding of the study are presented and interpreted as follows: Table 1 shows sample locations and amount of samples collected from three (3) different areas namely residential, farm land and market areas, fifteen (15) samples were collected from each location, where a total of thirty six (36) samples were collected. Ten (10) suspected fungi species namely, Mucor racemosus, Aspergillus Niger Penicillium chrysogenum, Rhizopus oryzae, Microsporum sp, Trichoderma sp, Nocardia $\mathrm{sp}$, Chaetomum sp, Fusarium sp, and Monilla sp were isolated from maize cobs.

\begin{tabular}{|c|c|c|}
\hline Samplelocation & Number of samples collected (n=36) & Fungal specieisolated \\
\hline A(residential) & 12 & $\begin{array}{c}\text { Rhizopus oryzae, Penicillium chrysogenum, Nocardia sp, } \\
\text { Aspergillus niger }\end{array}$ \\
\hline B (Farm land) & 12 & $\begin{array}{c}\text { Mucorracemosus, Aspergillusniger, Microsporum sp } \\
\text { Chaetomum sp, Trichoderma sp, Monilla sp }\end{array}$ \\
\hline C (Market place) & 12 & Chaetomumsp, Fusariumsp Rhizopusoryzae \\
\hline
\end{tabular}

Table 1: Fungi isolated from disposed maize cobs from different locations.

KEY: A, B, C = Locations.

\section{Amylolytic Potential of the Fungal Isolates}

The amylolytic activity tested based on starch - iodine reaction of fungi on starch agar medium (Table 2). Out of 10 fungi isolated (39.5\%) showed amylolytic activity, these organisms include Aspergillus Niger Mucor racemosus,
Penicillium chrysogenum, Rhizopus oryzae. Aspergillus Niger having the highest amylase activity as shown by the zone of clearance $(0.21 \mathrm{~cm})$ followed by Penicillium chrysogenum $(0.33 \mathrm{~cm})$ while Mucor racemosus showed the lowest amylase activity $(0.69 \mathrm{~cm})$.

\begin{tabular}{|c|c|c|}
\hline Fungi & Zone of clearance & Starch-iodine reaction test interference \\
\hline Rhizopus oryzae & $++(0.48 \mathrm{~cm})$ & $+\mathrm{ve}$ \\
\hline Fusarium sp & - & $-\mathrm{ve}$ \\
\hline Mucor racemosus & $+(0.69 \mathrm{~cm})$ & $+\mathrm{ve}$ \\
\hline Monilla sp & - & $-\mathrm{ve}$ \\
\hline
\end{tabular}




\section{Open Access Journal of Microbiology \& Biotechnology}

\begin{tabular}{|c|c|c|}
\hline Penicillium chrysogenum & $+++(0.33 \mathrm{~cm})$ & $+\mathrm{ve}$ \\
\hline Aspergillus niger & $++++(0.21 \mathrm{~cm})$ & $+\mathrm{ve}$ \\
\hline Microsporum sp & - & $-\mathrm{ve}$ \\
\hline Trichoderma $\mathrm{sp}$ & - & $-\mathrm{ve}$ \\
\hline Nocardia $\mathrm{sp}$ & - & $-\mathrm{ve}$ \\
\hline Chaetomum $\mathrm{sp}$ & - & $-\mathrm{ve}$ \\
\hline
\end{tabular}

Table 2: Amylolytic potential of fungal isolates based on starch-iodine reaction test.

KEYS: The sign $(+)$ indicates the positive screening test and $(-)$ indicates a negative screening test. The number of $(+)$ mark ranging from $1+$ to $3+$ indicates the level of hydrolysis by the zone of clearance around the colony. However, $6(60.1 \%)$ of the fungi grown on the starch agar medium and tested for their amylase activity based on starch agar reaction test were negative and did not show any zone of clearance these fungi include Microsporum sp, Trichoderma sp, Nocardia sp, Chaetomum sp, Fusarium sp, Monilla sp, these correspond with the work of [19] who identified amylolytic activity from several fungal species isolated from soil and Aspergillus sp possess the highest amylase activity producing extracellular amylase using (wheat, rice, and black gram bran).

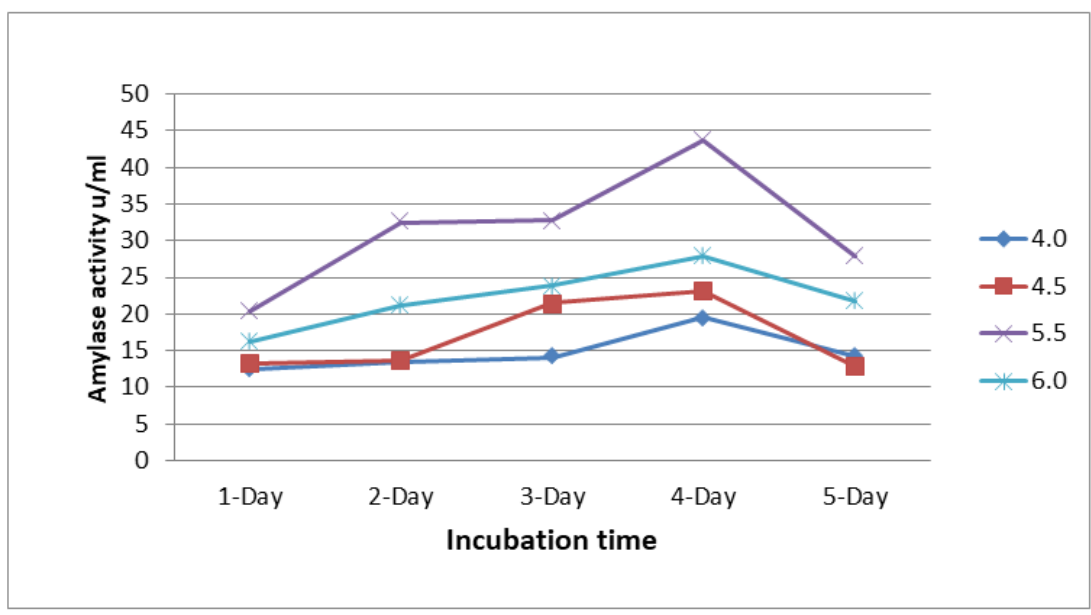

Figure 1: Effect of $\mathrm{pH}$ in the production of amylase using Penicillium chrysogenum.

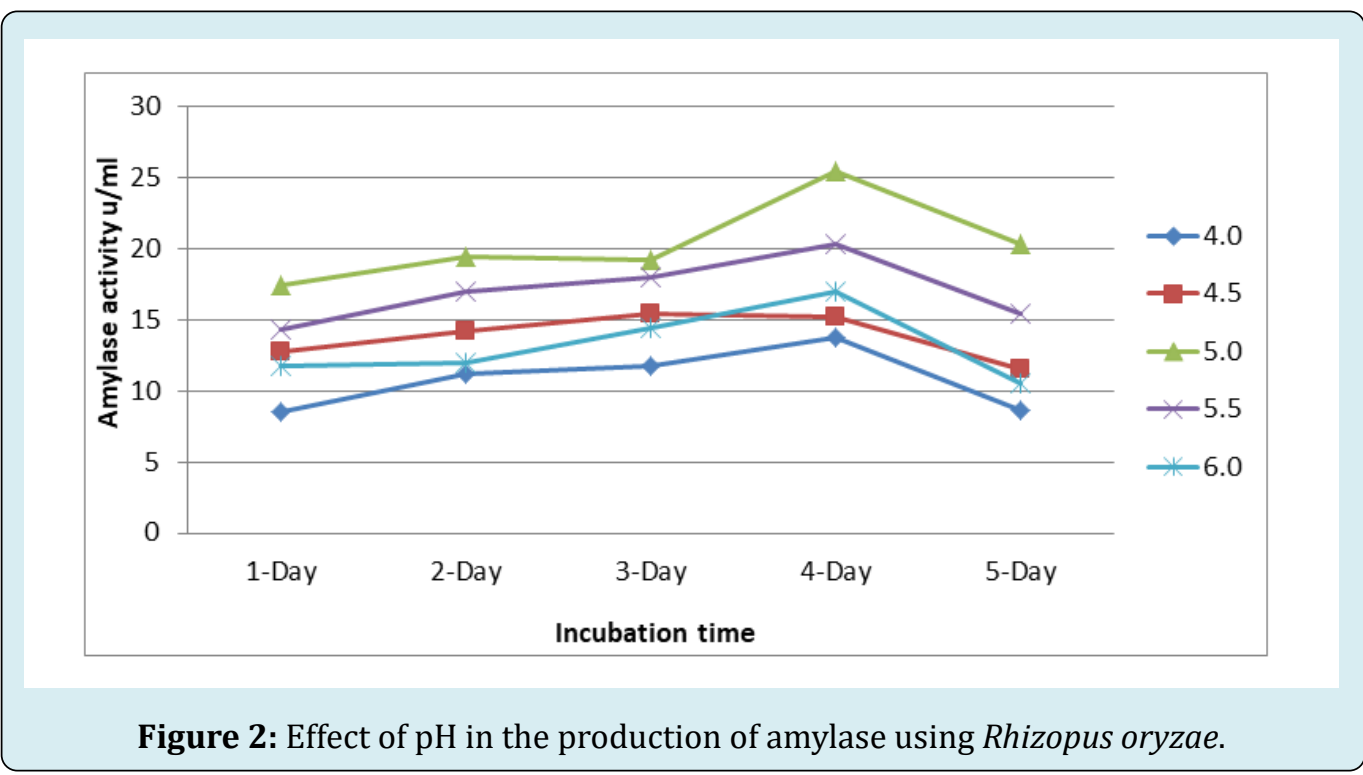




\section{Open Access Journal of Microbiology \& Biotechnology}

In this study, Figure 1 shows Penicillium chrysogenum having an optimum $\mathrm{pH}$ of 5.5 the amylase activity produced was $(43.6 \pm 11.1 \mu / \mathrm{ml})$. Aspergillus sp, such as A. oryzae, A. ficuum and A. Niger exhibit optimal production at $\mathrm{pH}$ 5.0-6.0 in Solid state fermentation [20]. The effect of $\mathrm{pH}$ (Figure
2) shows that Rhizopus oryzae with the $\mathrm{pH}$ of 5.0 and the amylase activity produced was $(25.5 \pm 9.5 \mu / \mathrm{ml})$. According to Kathiresan K, et al. [21] during production of $\alpha$-Amylase from $P$. fellutanum optimum $\mathrm{pH}$ was found to be within the range of 6.0 to 7.0 .

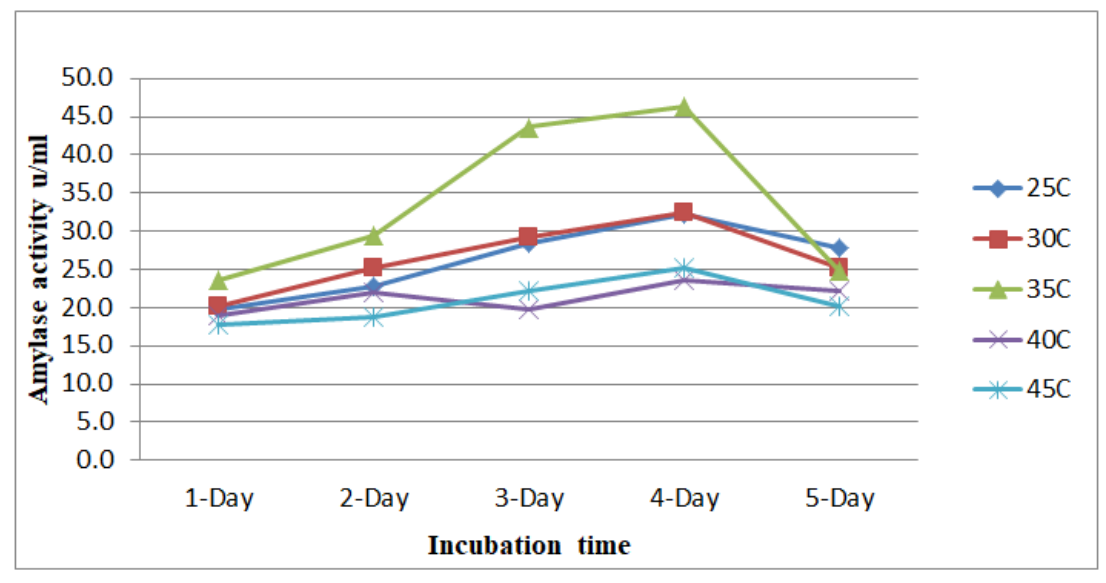

Figure 3: Effect of temperature in the production of amylase using Penicillium chrysogenum.

The present research recorded $35^{\circ} \mathrm{C}$ as optimum temperature for Penicillium chrysogenum as shown in Figure 3 with amylase activity of $(46.3 \pm 15.1 \mu / \mathrm{ml})$.An optimal temperature of $50^{\circ} \mathrm{C}$ was observed when temperature was varied within a range of $30^{\circ} \mathrm{C}-90^{\circ} \mathrm{C}$ for production of $\alpha$-Amylase by Aspergillus oryzae [22] When solid state fermentation was carried out for production of the enzyme by Aspergillus niger a range of $30-65^{\circ} \mathrm{C}$, the optimum temperature was found to be $60^{\circ} \mathrm{C}[23]$ this did not agree with the recent findings for Penicillium chrysogenum. Figure
4 shows optimum temperature of Rhizopus oryzae at $30^{\circ} \mathrm{C}$, amylase production was $(30.8 \pm 14.9 \mu / \mathrm{ml})$. According to Adeniran $\mathrm{AH}$, et al. [24] optimum temperature for amylase production was found ranging between $25^{\circ} \mathrm{C}$ and $37^{\circ} \mathrm{C}$ for the mesophilic fungi, which agrees with earlier findings, that influence of temperature on amylase production is related to the growth of microbes. Sethi S, et al. [25] also reported the influence of temperature on extra cellular enzymes secretion. This could probably be as a result of varying of the functional properties of the cell membrane.

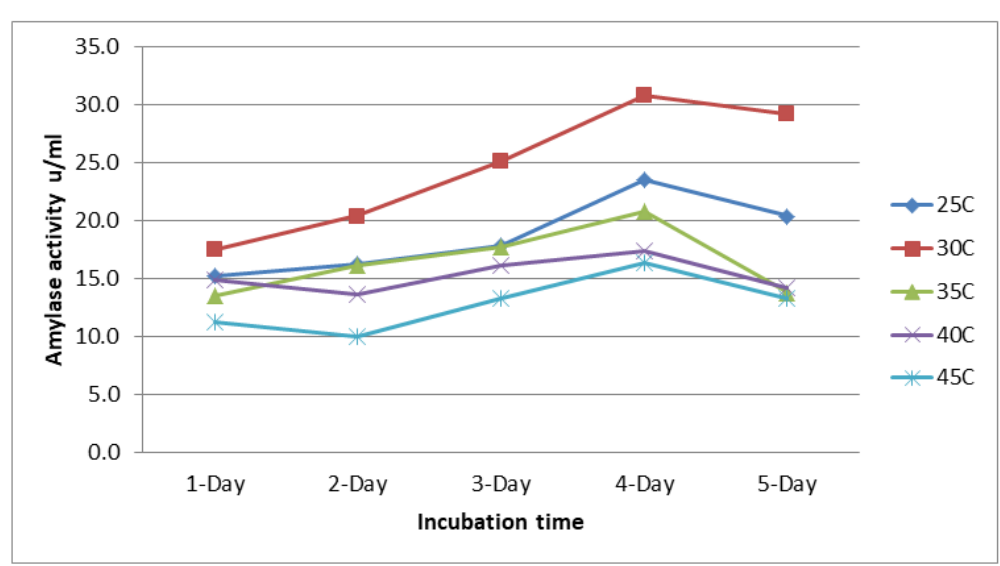

Figure 4: Effect of temperature in the production of amylase using Rhizopus oryzae.

The temperature has been observed to significantly influence enzymes production by the fungi [26]. Hence, the resistance to extreme temperatures, $\mathrm{PH}$ and pressure by the microorganisms and synthesis of particular enzymes are 


\section{Open Access Journal of Microbiology \& Biotechnology}

necessary for their adaptive response [27]. The microbial presences in such condition are of enormous importance for the exploration of biodiversity in biotechnology [14].

\section{Conclusion}

The use of solid state fermentation for the production of $\alpha$-amylase using Penicillium chrysogenum and Rhizopus oryzae, is an economical process and is very simple to apply. The substrate maize cobs support the production of amylase production using Penicillium chrysogenum and Rhizopus oryzae under solid state fermentation. However, this substrate made enzyme production high therefore maize cobs is a good substrate for the production or synthesis for $\alpha$ amylase using Penicillium chrysogenum and Rhizopus oryzae by solid state fermentation.

\section{References}

1. Krishnamurthi A (2004) The wealth of India: A dictionary of Indian raw materials. Vol. III, Publication information Directorate CSIR, New Dehli, pp: 349.

2. Gebeshuber G (2011) Energetische Nutzung von Maisspindeln. Landwirtschaftskammer Oberosterreich LKOO, Wels, Austria.

3. Kader AJ, Omar O, Feng LS (1999) Isolation of Cellulolytic Fungi from the Bario Highlands, Sarawak. ASEAN Review of Biodiversity and Environmental Conservation pp: 1-3.

4. Onofre SB, Steilmann P, Bertolini J, Rotta D, Sartori A, et al. (2011) Amylolytic Enzymes Produced by the Fungus Colletotrichum Gloeosporioides in Rice Semi-Solid Fermentation. Journal Yeast Fungal Research 2(3): 2832.

5. Gupta R, Gigras P, Mohapatra H, Goswami VK, Chauhan B (2003) Microbial amylases: a biotechnological perspective. Process Biochem 38(11): 1599-1616.

6. Rajagopalan G, Krishnan C (2008) $\alpha$-amylase production from catabolite derepressed Bacillus subtilis KCC103 utilizing sugarcane bagasse hydrolysate. Bioresour Technol 99(8): 3044-3050.

7. Kandra L (2003) $\alpha$ - Amylases of medical and industrial importance. Journal of Molecular Structure THEOCHEM 666-667: 487-498.

8. Sidkey NM, Shadi MAA, Balahmar R, Sabry R, Badrany G (2011) Purification and characterization of $\alpha$-amylase from a newly isolated Aspergillus flavus F2Mbb. Intternational Residual journal Microbiology 2(3): 96103.
9. Milala MA, Shugaba A, Gidado AA, Ene AC, Wafar JA (2005) Studies on the Use of Agricultural Wastes for Cellulase Enzyme Production by Aspergillus niger. Research Journal of Agriculture and Biological Sciences 1(4): 325-328.

10. Sanghvi GV, Koyani R, Rajput KS (2011) Isolation, optimization, and partial purification of amylase from Chrysosporium asperatum by submerged fermentation. J Microbiol Biotechnol 21(5): 470-476.

11. Jin B, Leeuwen HJV, Patel B, Yu Q (1998) Utilisation of starch processing wastewater for production of microbial biomass protein and fungal $\alpha$-amylase by Aspergillus oryzae. Bioresources Technology 66(3): 201206.

12. Cheesbrough M (2000) Medical Laboratory Manual for tropical countries. $2^{\text {nd }}(E d n)$, Butterwort \& Co. (Publishers) Ltd, UK, 1: 1-605.

13. Maki ML, Broere M, Leung KT, Qin W (2011) Characterization of some efficient cellulase producing bacteria isolated from paper mill sludge and organic fertilizers. International Journal of Biochemistry and Molecular Biology 2(2): 146-154.

14. Soares FL, Melo IS, Dias ACF, Andreote FD (2012) Cellulolytic bacteria from soils in harsh environments. World J Microbiol Biotechnol 28(5): 2195-2203.

15. Sohail M, Ahmad A, Shahzad S, Khan SA (2005) A survey of amylolytic bacteria and fungi from native environmental samples. Pak J Bot 37(1): 155-161.

16. Kwatia S, Dzogbefia VP, Ofosu IW (2017) optimization of amylase production by aspergillus niger cultured on yam peels in solid state fermentation using response surface methodology. African Journal of Biochemistry Research 11(7): 34-42.

17. Bedan DS, Aziz GM,Al Sa'ady AJR (2014) Optimum Condition for $\alpha$ - Amylase Production by Aspergillus niger Mutant Isolate using Solid State Fermentation. Current Research in Microbiology and Biotechnology 2(4): 450456.

18. Sivaramakrishnan S, Gangadharan D, Nampoothiri KM, Soccol CR, Pandey A(2006) $\alpha$ - amylases from Microbial sources. An overview on recent developments. Food Technology and Biotechnology 44(2): 173-184.

19. Alva S, Anupama J, Savla J, Kumudini BS, Varalakshmi KN, et al. (2007) Production and characterization of fungal amylase enzyme isolated from Aspergillus sp. in solid state culture. African of Journal of Biotechnology 6(5): 


\section{Open Access Journal of Microbiology \& Biotechnology}

576-581.

20. Laderman KA, Lewis MS, Griko YV, Privalov PL, Anfinsen CB, et al. (1993) The purification and characterization of an extremely thermostable alpha-amylase from the hyperthermophilic archaebacterium Pyrococcus furiosus. J Biol Chem 268(32): 24394-24401.

21. Kathiresan K, Manivannan S (2006) Amylase production by Penicillium fellutanum isolated from mangrove rhizosphere soil. African Journal of Biotechnology 5(10): 829-832.

22. Ramachandran S, Patel A, Nampoothiri KM, Chandran S, Ashok P, et al. (2004) Alpha Amylase from a fungal culture grown on oil cakes and its properties. Brazilian Archives of Biology and Technology 47(2): 309-317.

23. Omemu AM, Bankole MO, Akpan I (2008) Production and characterization of Extracellula. amyloglucosidase from Aspergillus niger CA-19 by SSF. Research Journal of Microbiology 3: 129-135.

24. Adeniran AH, Abiose SH (2009) Amylolytic potentially of fungi isolated from some Nigerian Yeast and agricultural wastes. African Journal of Biotechnology 8(4): 667-672.

25. Sethi S, Datta A, Gupta BL, Gupta S (2013) Optimization of cellulase production from bacteria isolated from soil. ISRN Biotechnol pp: 985685.

26. Fagade 0, Bamigboye 00 (2012) Effect of cultural conditions on the cellulase activity of bacteria species isolated from degrading corn cob. Archives of Applied Science Research 4(6): 2540-2545.

27. Clarke A (2003) Evolution, adaptation and diversity: global ecology in an Antarctic context. In: Huiskes AD, et al. (Eds.), Antarctic biology in a global context. Backhuys Publishers, Leiden, pp: 3-17. 